\title{
GARGOYLISM IN A TWIN BROTHER AND SISTER
}

\author{
BY \\ W. S. CRAIG \\ From the Department of Paediatrics and Child Health, the University of Leeds
}

(RECEIVED FOR PUBLICATION MARCH 17, 1954)

Gargoylism has been the subject of several comprehensive reviews within recent years. The liability of siblings to be affected is established. There are a number of recorded instances of gargoylism affecting one of twins but involvement of both children of a twin delivery is rare. Nonne (1925) described twin sisters both of whom were affected. His publication contains no reference to the appearance or structure of the placenta. In 1917 Hunter described gargoylism in two brothers aged 10 and 8 years. The mother of these children gave birth to full-term twins who died after a difficult delivery and whose heads were noted as being unusually large. It is remotely possible that the children of this twin pregnancy were both gargoyles. The sexes of the twins are not stated. I have been unable to find any record of gargoylism affecting both children of different sexes in a twin pregnancy.

Of the twins the subject of this contribution one was a boy and the other a girl. They were first seen at the age of 8 months and were kept under periodical clinical supervision until death at the age of 4 years 8 months in the case of the boy, and at the age of 7 years in the case of the girl. Valuable information concerning the progress of the twins before their first attendance at hospital was obtained from the mother and maternal grandmother, who, within the limits of their knowledge, could not have been more reliable, accurate or cooperative informants. Clinical study of the two children was supplemented by ophthalmological and radiological examinations during life and by pathological and histochemical examinations after death. Management of the children during life was concerned with a number of sociological problems.

\section{Family Background}

The father was a petty officer in the Royal Navy and was drafted to the Far East four months after the birth of the twins. Before her marriage the mother was in the Women's Royal Naval Service. At the time of conception she was aged 19 and the father 23 years. There had been no previous pregnancies, and there was nothing of note in the previous health record of either parent. The parents are not blood relations and show no abnormalities of appearance or of stature.

Enquiries extending back for three generations revealed no evidence of marriage between cousins in the mother's or the father's family. Careful inquiry into the family health records on both the maternal and paternal sides elicited two findings which might have a bearing on the occurrence of gargoylism. On the paternal side a sister of the twins' grandfather was deaf and dumb and died at approximately 3 years of age. When interviewed the father of this child described her appearance and behaviour as normal. A great-uncle of the twins on their mother's side is known to have had a kyphotic deformity of the spine, the deformity not having been noticed until the age of 3 years. The great-uncle in question lived for some 30 years, earned his livelihood as a mill-hand, distinguished himself as a long distance swimmer, married and had a family of three healthy children.

Photographs of this great-uncle and of a family group including the great-uncle and his brothers and sisters have been inspected. The photographs are extremely illuminating and it is regrettable that permission has not been obtained to reproduce them. Fig. 1 is of a tracing of the family group. There is no escaping the fact that every member of the family in the group is a dwarf. The three unrelated individuals in the group who are not blood relatives literally stand head and shoulders above their one adolescent and six adult companions. Furthermore the facio-cranial features of two brothers and one sister (i.e., two great-uncles and one great-aunt of the twins recorded in this article) are strikingly similar in the unusual prominence of the brow and mandible, the wide separation of the eyes, the heaviness of the lips and the coarse structure of the nose. It cannot be said, however, that the facial appearance of these individuals is typical of gargoylism or that the photographs suggest any 


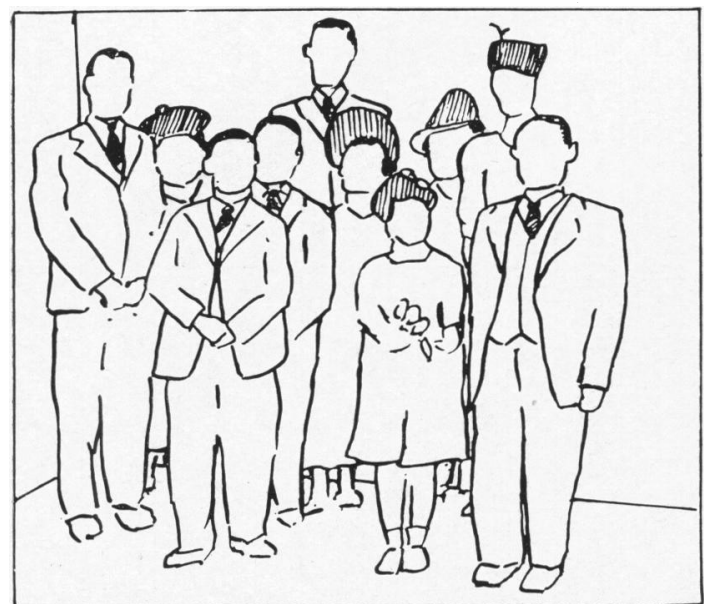

FIG. 1.-Tracing of photograph of a family group. The figure on the extreme right was the great uncle of the twins and was known to have had kyphosis and to have been a long distance swimmer. The three tallest members of the group are not blood relations of one another or of others in the group. The six other individuals are brothers or sisters of the figure on the extreme right.

abnormalities other than physical. The figures in the group are all standing facing the camera thus excluding any possibility of confirming the presence of kyphosis in the great-uncle first mentioned or in any of his brothers and sisters. There is recognizable shortening of all limbs in the dwarfed individuals who do not have the appearance of achondroplasia.

\section{Obstetrical History}

The expected date of delivery, based on the time of the last menstrual period, was August 17, 1946. Regular ante-natal supervision began in February of that year. Progress was uneventful until early June when oedema of the lower extremities was noted by the mother. On July 17 the fact that the abdomen was tense and larger than was to be expected having regard to the period of gestation led to the mother being radiographed. Films established the presence of a twin pregnancy (Fig. 2).

Labour pains began at 11 p.m. on July 30 . The mother was admitted to hospital on the same night, and a living female child was delivered normally at 2.55 a.m. on July 31 . Uterine contractions began again at 3 a.m. and delivery of a living male child took place at 3.15 a.m. Healthy and complete membranes were expelled at 3.30 a.m.

On examination by the labour ward staff immediately after delivery both infants were noted as being healthy and as showing no evidence of any developmental abnormalities. Mother and babies were discharged from hospital on August 9, 1946.

\section{The Clinical Histories}

Recognition of the Condition. The first twin (the girl) weighed $7 \mathrm{lb}$. and measured $20 \mathrm{in}$. in length at birth. The corresponding figures for the male infant were $7 \mathrm{lb} .6 \mathrm{oz}$. and $20 \mathrm{in}$. Records relating to the condition of the babies after birth are limited to notes that both twins cried lustily, and that routine prophylactic treatment for the eyes was given. The male child died on March 16, 1951, at the age of 4 years 8 months and the female child on July 29 , 1953, at the age of 7 years.

The first of the twins examined was Michael at the age of 8 months who was referred to me as an out-patient on account of chronic rhinitis with the suggestion that the condition was syphilitic. The heavy, frankly repulsive features of the child were unmistakable. Seven years later, some six months after the death of his second child, the father volunteered information which he had not mentioned previously to anyone. He said that when he first saw his newly born babies in hospital he sensed straight away that the boy was unlike any of the

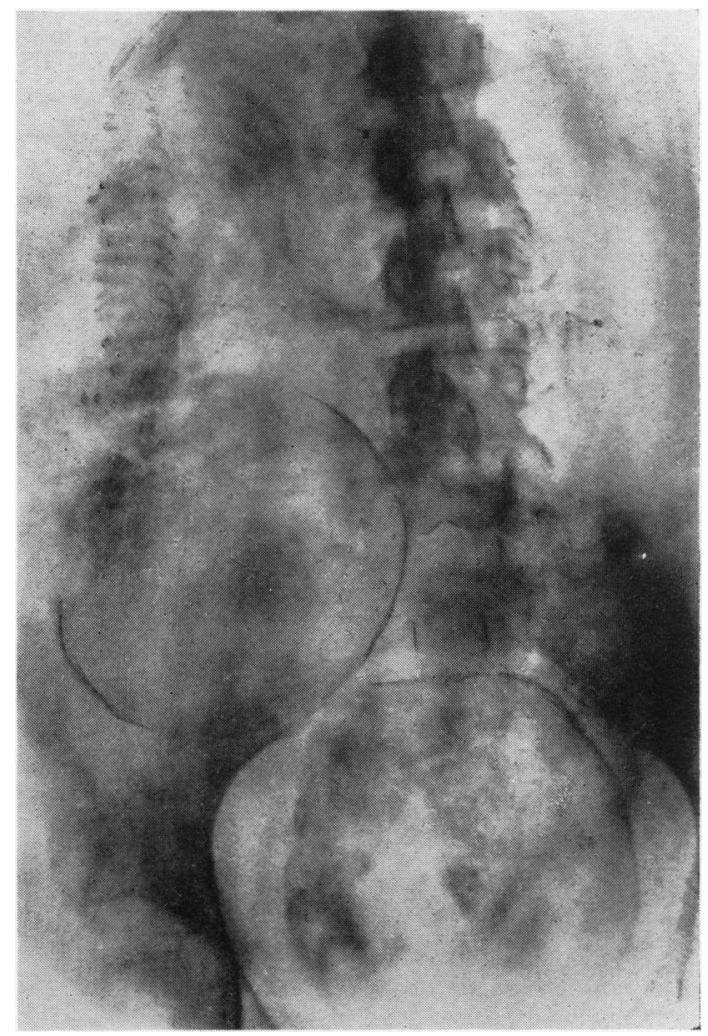

FIG. 2.-Radiograph taken two weeks before the onset of labour. There are no detectable bony abnormalities of the foetuses. 
other infants in the maternity nursery and was completely different in appearance from his twin sister. Asked what gave rise to his reaction the father replied, 'His (the boy's) head looked so big, and his face so coarse and heavy', and went on to say 'it wasn't until Jane was 3 months old that I suddenly realized she looked strange too. When I went abroad I had a feeling all was not well with my children but I didn't share my fears with anyone.'

At the time of first examination Michael had a gross angulated kyphosis affecting the thoracolumbar spine (Fig. 3). Some doubt existed as to how long this had been present. The grandmother stated that she had thought the child's chest and back were peculiarly shaped when he returned from the maternity hospital. Mother and grandmother were emphatic in their agreement that there was a 'bump' in the spine when the boy was 4 months old which interfered with his early attempts to sit up.

In the course of discussion these relatives casually volunteered the information that the shape of Michael's back resembled that of his twin sister. His sister (Jane) was brought up for examination 10 days later and was found to have a marked thoraco-lumbar kyphosis and the facial and other characteristics of gargoylism (Fig. 4). In the case of the sister the spinal deformity had not been noticed until she was between 6 and 7 months old.

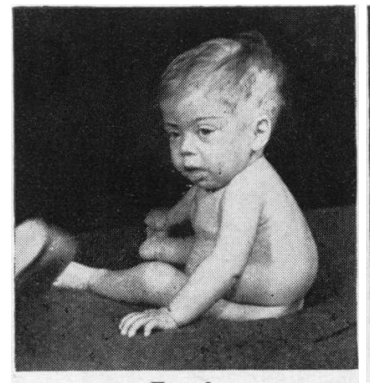

FIG. 3.

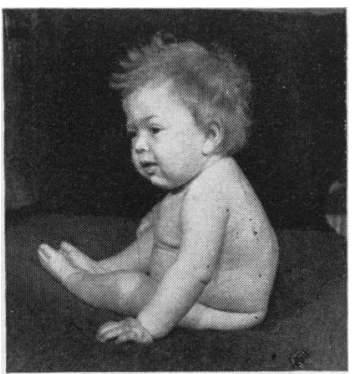

FIG. 4.
FIG. 3.-Michael I., aged 8 months, showing heavy facial features, kyphosis, chest deformity, claw hand and low-set ear.

FIG. 4.-Jane I., aged 8 months, showing features similar to Michael's (Fig. 2).

Fully Developed Clinical Picture. Clinical features common to both children included dwarfism in association with a large dolichocephalic head; the heavy, repulsive facial features implied in the term 'gargoyle' and evidenced in the eyes, ears, nose, cheeks and tongue (Fig. 5); teeth which were irregular in eruption and spacing; a notably short, thick-set neck; gross dorso-lumbar kyphosis accompanied by pronounced deformity of the chest; a notably protuberant abdomen with umbilical herniation and enlargement of the liver and spleen; coarse, thick skin and slight hirsutism; shortening of the limbs together with limited mobility of joints

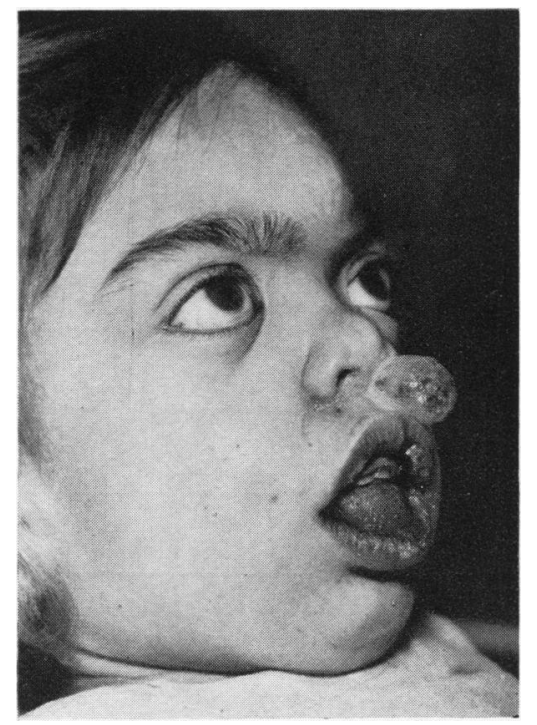

FIG. 5.-Jane I., aged 4 years 10 months, showing corneal opacity, rhinorrhoea, macroglossia and hypertrophied gums.

and 'claw hands'; and marked impairment of mental development together with striking abnormalities of behaviour pattern. Both children showed evidence of deafness, both had pronounced corneal opacity and in both radiographs showed bony changes typical of gargoylism (Fig. 14, 15).

Development of the Clinical Picture. Impaired physical development was evident in retarded progress of weight and height. Both children were recognizably retarded by the first birthday (Fig. 6). Table 1 shows the order of succession in the appearance of gross physical abnormalities. The order was the same in both twins but in general the age at which each abnormality was recognized was a few months greater in the case of the girl. Enlargement of the liver and spleen was most rapid in the case of the boy, in whom, partly as a result of the size of the organs and partly as a result of the skeletal deformities, the liver and spleen extended down into the pelvis. Opacity of the corneae was evident first in Michael but appeared to become arrested at the age of $3 \frac{1}{2}$ years. In contrast, opacity of the corneae in Jane became progressively worse. In the words of the father 'Michael always had a little sparkle in his eyes but Jane lost all hers'. 


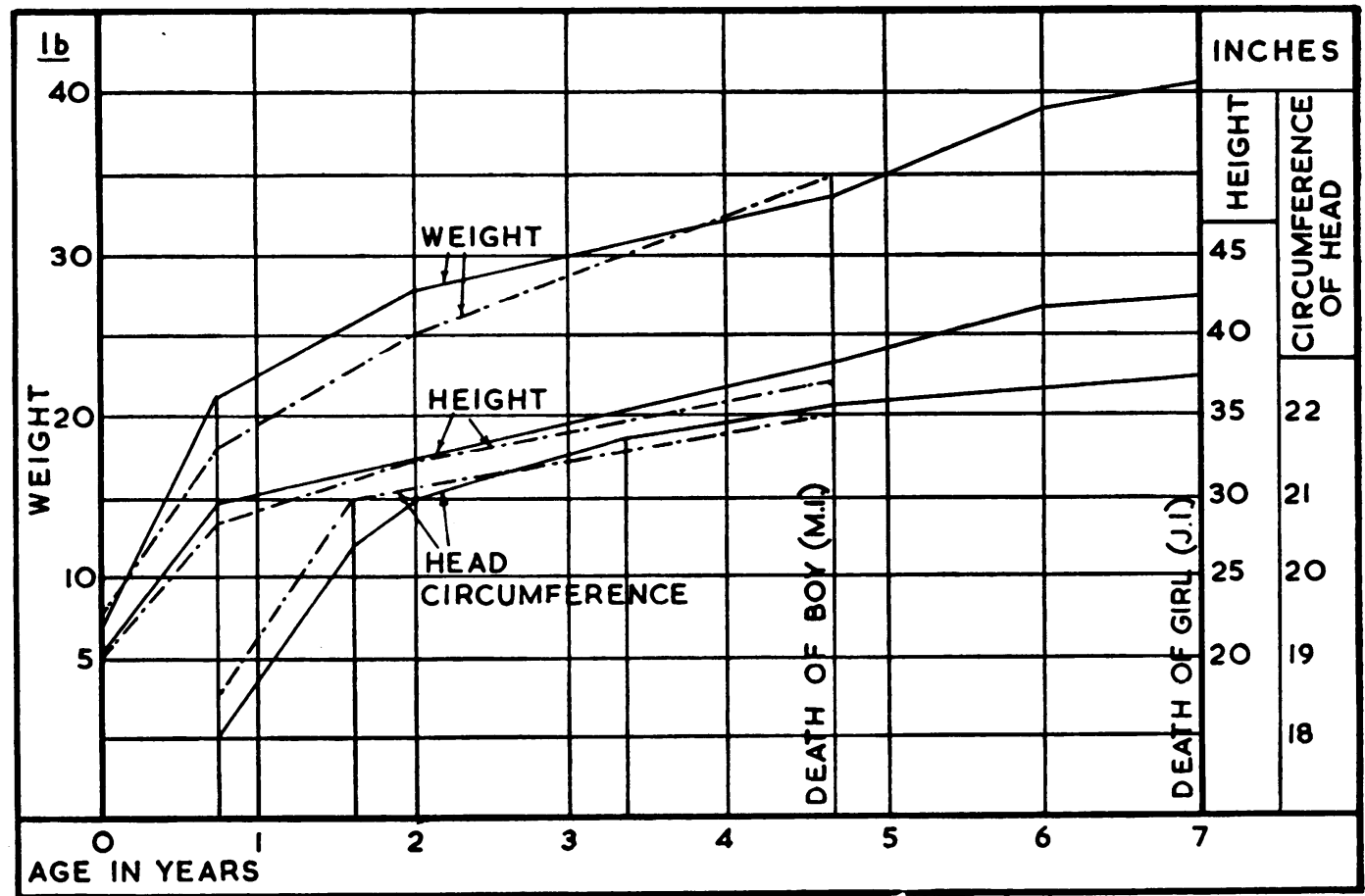

JANE I.

Fig. 6.-Weights, heights and circumference of heads compared at different ages.

TABLE 1

AGE OF FIRST RECOGNITION OF GROSS ANOMALIES

\begin{tabular}{|c|c|c|}
\hline \multirow[b]{2}{*}{ Abnormality } & \multicolumn{2}{|c|}{ Age } \\
\hline & Michael I. & Jane I. \\
\hline $\begin{array}{l}\text { Chronic rhinitis } \\
\text { Chronic recurrent conjunctivitis .. } \\
\text { Thoraco-lumbar kyphosis }\end{array}$ & $\begin{array}{l}\text { Birth } * \\
1 \text { month } \\
4 \text { months * } \\
\text { (? 2 weeks) }\end{array}$ & $\begin{array}{l}\text { Birth } * \\
1 \text { month } \\
7 \text { months }\end{array}$ \\
\hline $\begin{array}{l}\text { Deformity of chest } \\
\text { Heavy facial features } \ldots \\
\text { Humeri-thickening and shortening }\end{array}$ & $\begin{array}{l}2 \text { weeks * } \\
\text { At birth }\end{array}$ & $\begin{array}{l}7 \text { months } \\
4 \text { months }\end{array}$ \\
\hline $\begin{array}{llll}\text { of shafts } & \ldots & . & \ldots \\
\begin{array}{l}\text { Corneal opacities } \\
\text { Umbilical hernia }\end{array} & \ldots & \ldots \\
\text { Joints-limited extension } \\
\begin{array}{l}\text { Enlargement of liver } \\
\text { Enlargement of spleen }\end{array} \\
\begin{array}{l}\text { Hypertrophy of the gums } \\
\text { Strabismus } . .\end{array} & \ldots & \ldots \\
\end{array}$ & $\begin{array}{l}8 \text { months } \\
8 \text { months } \\
8 \text { months } \\
10 \text { months } \\
13 \text { months } \\
15 \text { months } \\
2 \text { years }\end{array}$ & $\begin{array}{l}8 \text { months } \\
11 \text { months } \\
7 \text { months } \\
12 \text { months } \\
17 \text { months } \\
19 \text { months } \\
2 \text { years } \\
2 \text { years } \\
6 \text { months }\end{array}$ \\
\hline Impaired hearing $\quad . \quad \ldots \quad \quad$. & $\begin{array}{l}2 \text { years } \\
6 \text { months }\end{array}$ & 2 years \\
\hline $\begin{array}{l}\text { Fissuring of tongue } \\
\text { Genu valgum } \\
\text { Heart_mitral systolic murmur } \\
\text { Heart-detectable clinical enlarge- } \\
\text { ment }\end{array}$ & $\begin{array}{l}\text { ב years } \\
10 \text { months } \\
4 \text { years }\end{array}$ & $\begin{array}{l}3 \text { years } \\
3 \text { years } \\
4 \text { years } \\
6 \text { months } \\
4 \text { years } \\
10 \text { months }\end{array}$ \\
\hline 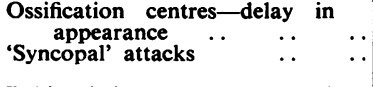 & 4 years & $\begin{array}{l}4 \text { years } \\
5 \text { years } \\
2 \text { months }\end{array}$ \\
\hline \begin{tabular}{llll}
\multicolumn{3}{l}{ Babinski sign, exaggerated tendon } \\
reflexes .. &. &. & \\
Increased muscle tone &.. & $\ldots$
\end{tabular} & - & $\begin{array}{l}5 \text { years } \\
9 \text { months } \\
6 \text { years } \\
1 \text { month }\end{array}$ \\
\hline
\end{tabular}

* Retrospective observations made by relatives
Delay in the acquisition of locomotor control was related to the degree of physical handicap. Kyphosis appeared first and in severer degree in the boy and resulted in his being slow to sit, stand and walk compared with his sister (Fig. 7). Jane first experienced serious locomotor handicap at the age of approximately 18 months. As the rate of growth increased spinal and thoracic deformities became aggravated and the abdomen enlarged rapidly (Fig. 8). From this time the boy's progress in the

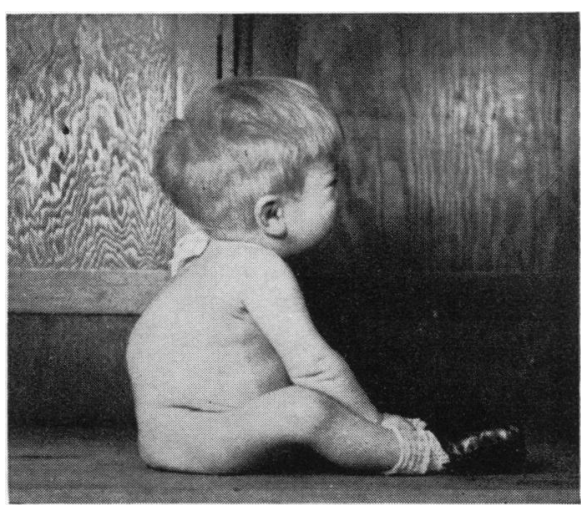

FIG. 7.-Michael I., aged 21 months, showing increased kyphosis. 
matter of locomotor control was always markedly in advance of that of his sister. After his death at the age of 4 years 8 months Jane continued to grow rapidly. Walking without assistance became impossible and during the last year of her life she made no attempt to walk.

There was less evident parallelism in the matter of the emotional and behaviour pattern of the two children (Table 2). During the first year of life Michael compared unfavourably with his sister Jane. Lazy and disinterested he was never successfully breast fed and continued to present a management problem during the whole of the 6 months he was on the bottle. He was a notably irritable infantalways crying for no apparent reason at any, but no regular, time of day or night. In contrast Jane

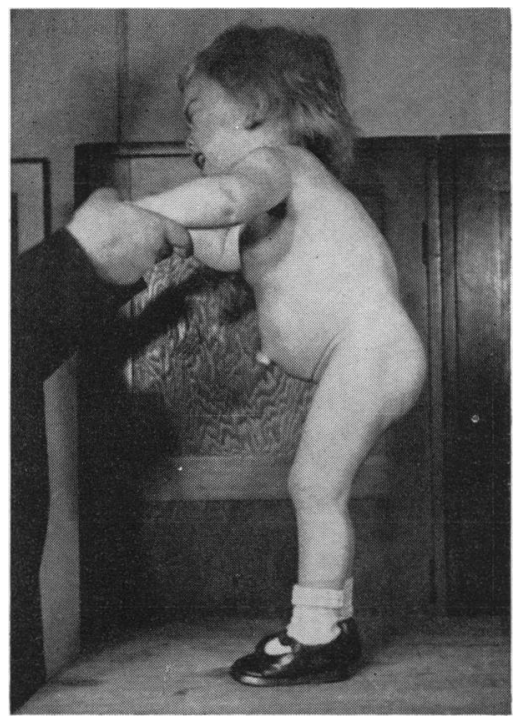

FIG. 8.-Jane I., aged 21 months, showing chest deformity, large abdomen, umbilical hernia and difficulty in balancing.

fixed eagerly and effectively from the time she was first put to the breast. Her response to bottle feeding, begun at the age of 3 months, was that of a normally appreciative infant. She was noticeably content without being too quiet.

The contrast between brother and sister was completely reversed in many respects after their first birthday. Discontent and disinterest in the boy gave place to unmistakable evidence of interest, enjoyment and a desire to do things. Attempts at speech followed and where there had been no response to parental attention there was now unmistakable delight, dependence and affection. Jane on the other hand betrayed no recognizable signs of affection. Temperamentally she became completely changed (Fig. 9). From being quietly content she became aggressive alike in her demands and in her responses. Consistently ill-tempered where formerly

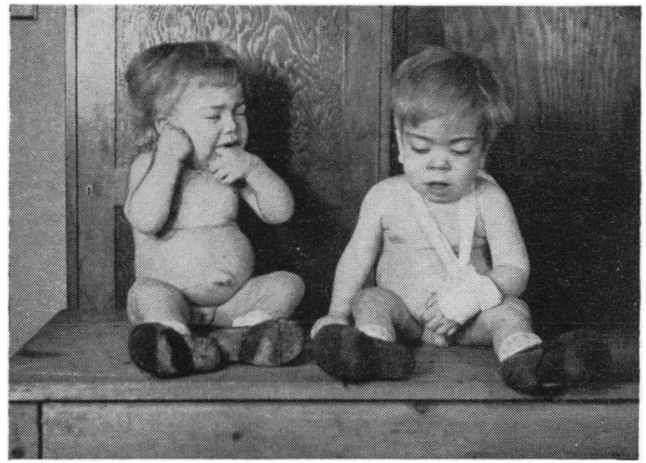

Fig. 9.-Jane I. (left) and Michael I. (right), aged 21 months.

she had been placid she developed a tendency to irrational tantrums and intolerant bouts during which she would attack her brother and reject her mother with a measure of violence (Fig. 10).

As Michael showed increasing readiness to consider but not necessarily accept strangers, Jane showed progressively less and less interest in her surroundings and in those around her. Michael put his knowledge of pictures, bricks and toys to good purpose. He showed a certain originality and initiative and sensed a thrill in building up bricks only to knock them down.

Whereas the boy acquired a measure of cleanliness of habits by the third year, Jane was always dirty. Relatives in the home and the staff of the occupation centre attended by the children commented upon the regularity with which both children

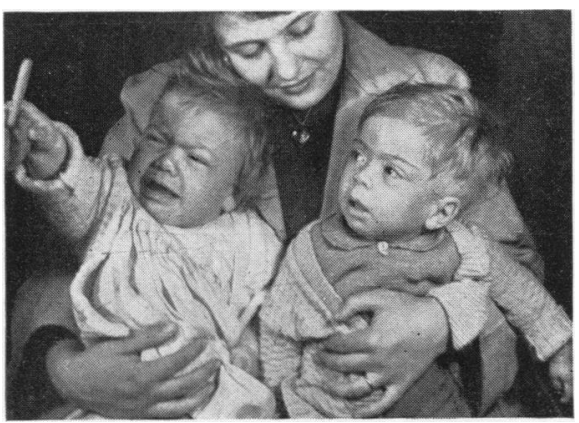

FIG. 10.-Jane I. (left) and Michael I. (right), aged 9 months with their mother.

habitually passed exceptionally bulky offensive motions within half an hour of every meal. In seven years ' $\mathrm{Ta}$ ' and 'Bye-bye' were the only 
TABle 2

DEVELOPMENT OF LOCOMOTOR FUNCTION, SKILLS, BEHAVIOUR PATTERN, ETC.

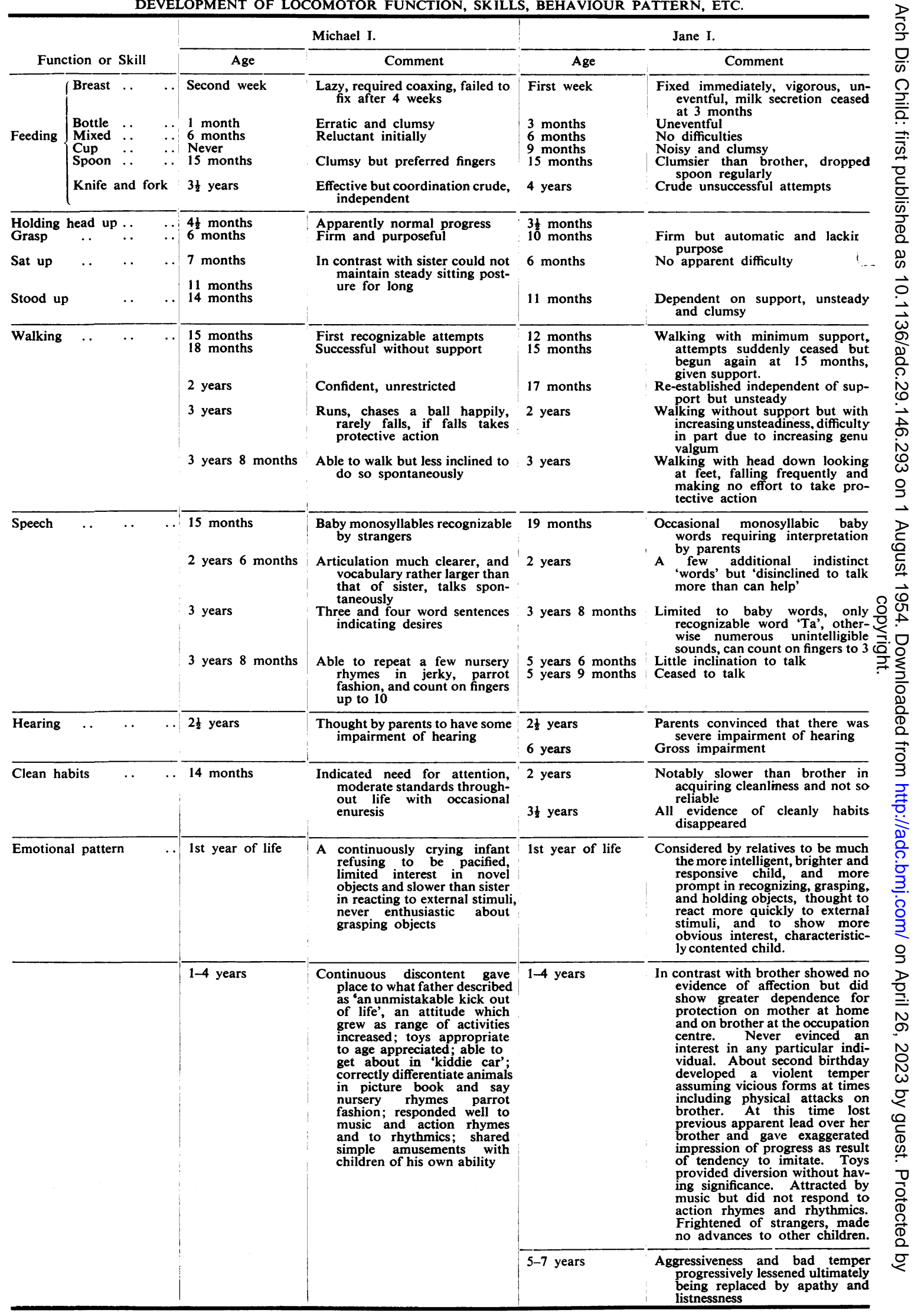


intelligible words Jane was heard to utter. On the other hand during the last year of his life Michael was able to say simple sentences understandable to those accustomed to his poor articulation. Difficulty in speech was contributed to in both children by impaired hearing first noticed about the age of 2 years, chronic rhinitis and macroglossia.

It is doubtful whether Jane was conscious of any serious loss as the result of her brother's death. Her parents do not think she was affected. At the age of 5 or thereabouts her behaviour underwent another change. Her bad temper and aggressiveness ceased. Thereafter a slowly progressive decline began. The child became more and more listless until a state of sustained physical inactivity and something approaching mental torpor was reached.

Miscellaneous Points Relating to Health Histories. Catarrh of the mucous membranes was a feature of both children from birth. The twins were alike in suffering throughout life from persistent mucopurulent rhinitis and recurrent purulent ophthalmia. Jane had measles at 9 months, bronchitis at the age of 17 months and an intermittent vaginal discharge during the last 18 months of life associated with persistent masturbation.

Michael was never a hospital in-patient. Jane on the other hand was admitted on four occasions: at the age of 5 weeks on account of severe conjunctivitis; at the age of 2 years 4 months for radical cure of an incapacitatingly large hernia which had increased in size after the child began to walk; at the age of 4 years 9 months with an acute respiratory infection and threatening cardiac failure; and at the age of 7 years on the occasion of her final illness. As well as being treated as an in-patient Jane attended an orthopaedic department where she was given an abdominal belt at the age of 3 years 1 month with the object of offsetting her difficulty in balancing, a mermaid splint at the age of 3 years 10 months intended to minimize additional difficulties in walking arising from increasingly pronounced genu valgum, and a corset at the age of 5 years to minimize incapacity resulting from advancing skeletal deformities.

The corset proved of considerable value in enabling the girl to move about with greater although hesitant independence, but had an unexpected result. Following recovery from her serious illness at the age of 4 years 9 months the child had been subject to periodical attacks of acute respiratory embarrassment, cyanosis, tachycardia and apparent pain. The attacks were precipitated by exercise, responded to rest and were regarded as evidence of myocardial insufficiency. An immediate result from the wearing of the corset was to increase the frequency and severity of the attacks. Benefit followed as soon as the corset was discarded.

A mitral systolic murmur lacking selective propagation was noted in Michael at the age of 3 years 10 months. Cardiac enlargement was clinically detectable at 4 years. Similar findings appearing in the same sequence were detected in Jane at the ages of 4 years 6 months and 4 years 10 months. The findings persisted throughout life and in the case of Jane the murmurs increased in loudness and harshness. Electrocardiographic records showed right deviation in both twins.

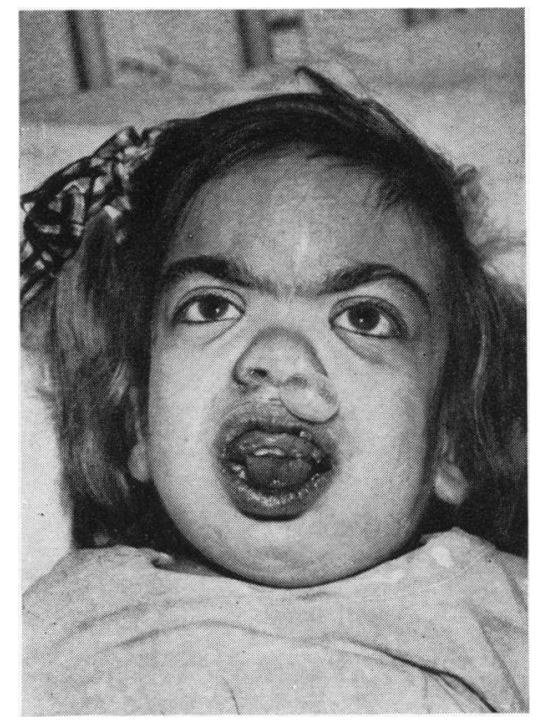

FIG. 11.-Jane I., aged 4 years and 10 months, showing hypertrophied gums. Note also the characteristic facial feature and macroglossia.

The first dentition was not delayed in the case of Michael. The two lower central incisors erupted at the age of 5 months. He had four teeth at the age of 9 months, six at the age of 12 months and 16 at the age of 2 years. Jane cut her first two teeth at the age of 10 months. Eight additional teeth appeared more or less simultaneously shortly before the second birthday. About this time the gums became grossly hypertrophied, nodular in consistence and rather deeply coloured. Similar but much less pronounced changes in the gums were seen in Michael. The alveolar changes persisted throughout life in both children despite suitable diet and adequate vitimins (Fig. 11).

Examining the twins at the ages of 2 and 4 years Professor Talmage Read of the Leeds Dental School 


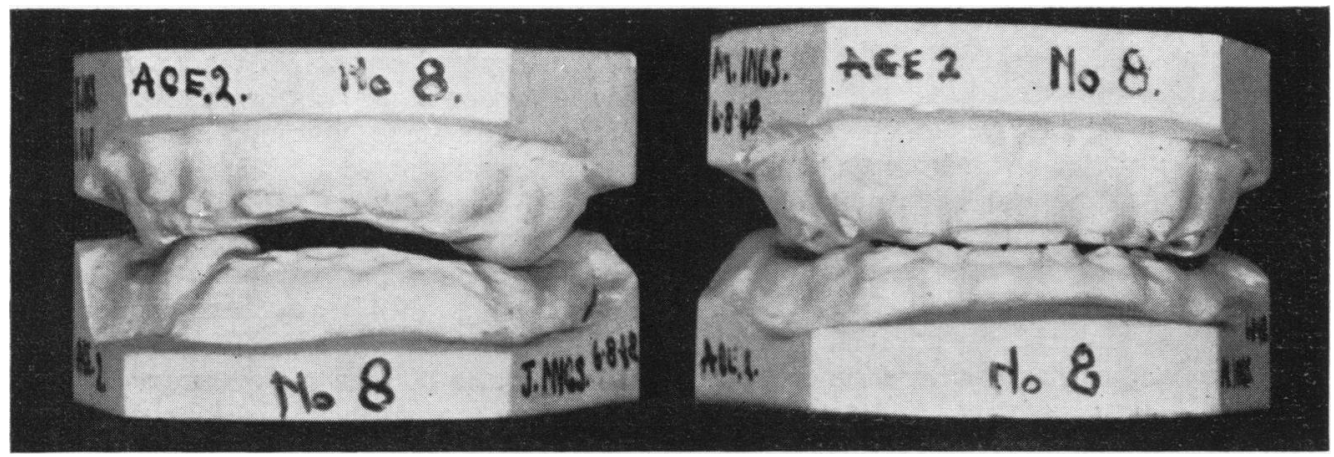

FIG. 12.-Dental casts showing abnormal spacing, irregular alignment and malocclusion (Jane left, Michael right, aged 4 years).

described the erupted teeth as being well calcified and free from dental caries, but abnormally spaced and irregular in alignment and occlusion (Fig. 12). The abnormalities were more pronounced in the girl than in the boy. Radiographs of the jaws demon-
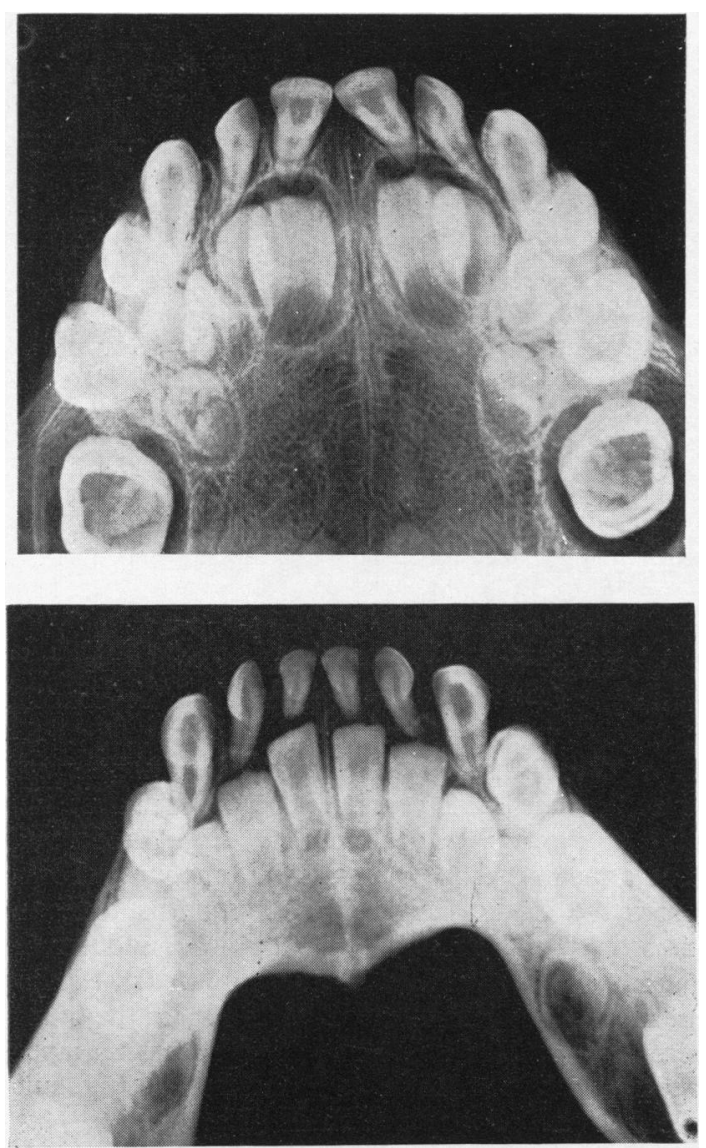

Figs. 13A and B.-Radiograph of Michael, aged 4 years, showing well advanced calcification of deciduous and unerupted permanent teeth. strated that in both children teeth were present according to age and that calcification of the teeth was if anything in advance of what might have been expected (Figs. 13a and 13b).

Radiographs of the skeleton taken at the age of 8 months showed maldevelopment of several vertebrae and posterior displacement of the second lumbar vertebra in Michael (Fig. 14), deformity of the bodies of the upper lumbar vertebrae in Jane

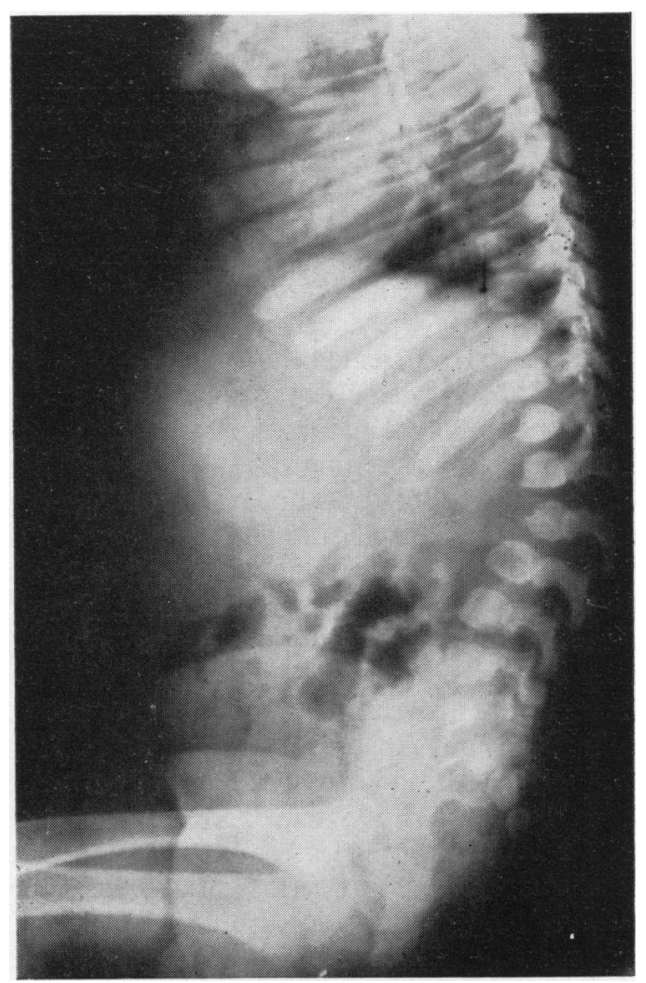

Fig. 14.-Radiograph of Michael at 8 months showing maldevelopment and posterior displacement of the second lumbar vertebra. 
(Fig. 15) and shortening and thickening of the shaft of the humeri in both children. There were no abnormalities of the cranial bones or of the bones

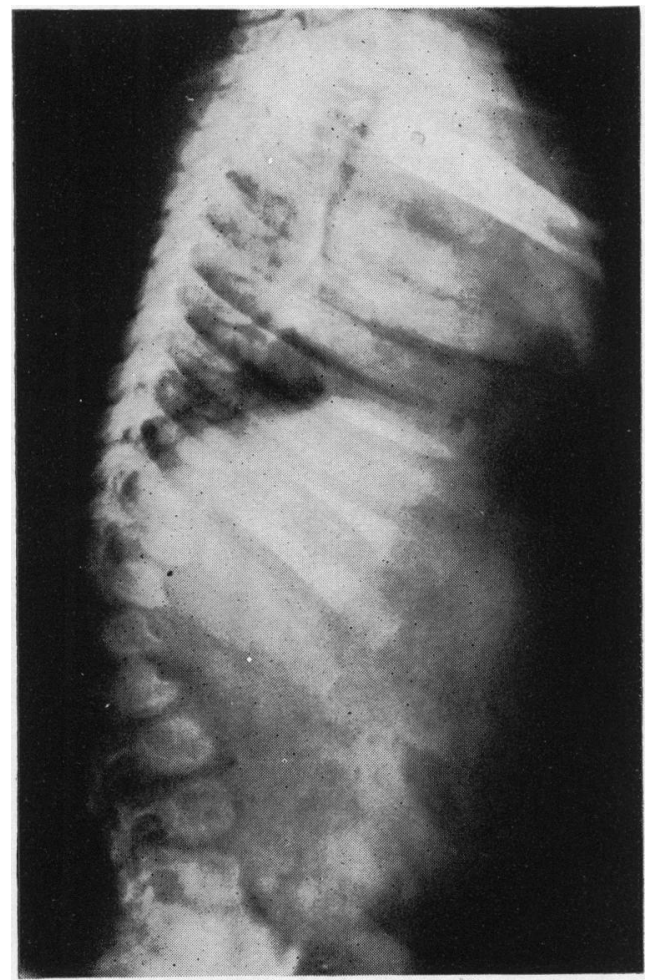

FIG. 15.-Radiograph of Jane at 8 months showing deformity of the bodies of the upper lumbar vertebrae.

of the lower limbs. The appearance of the ossification centres was in keeping with the age. Follow-up radiographs at the age of 1 year 7 months demonstrated that the girl's lower limbs had grown more rapidly than those of her brother. Films taken at the age of 4 years showed delay in the appearance of ossification centres and changes typical of gargoylism in the bones of the hands and feet, the long bones of all extremities, the pelvis, spine and skull of both twins.

Laboratory examinations were limited to analyses of urine and estimations of the urea-nitrogen, calcium, phosphorus and alkaline phosphatase blood levels. All findings were within the normal range. Wassermann and Mantoux tests were negative. Both children had a mild hypochromic anaemia associated with slight leucocytosis with a relative increase in polymorphonuclear cells. No abnormal granularity of the polymorphonuclear leucocytes was detected.
Circumstances of Deaths. On March 9, 1951, the parents suspected that the boy might have a painful ear. Six days later (March 15) he had a cough, appeared feverish and showed signs of moderate respiratory embarrassment. The doctor was sent for but the child died before his arrival. Postmortem examination established that death was due to bronchopneumonia.

Jane was admitted to hospital on July 26, 1953, with a history of descending respiratory infection and with clinical evidences of extensive bronchitis and commencing heart failure. She died within two days of admission.

Social Problems. Inevitably any explanation of the implications of the diagnosis involved asking the mother to show great courage in accepting a situation inseparable from extreme emotional and physical demands. She could not have faced the situation with greater fortitude. In this she received invaluable understanding and practical help from her own mother. Meanwhile the facts of the situation were made known to the appropriate Service family welfare department, and as a result the father was released from service on compassionate grounds and enabled to return home without delay.

Although able to move about independently, the movements of the children were precarious and even given the best of conditions liable to be punctuated by frequent falls. The only outside play-space available to the children consisted of a small cobbled yard approached from the house by steep stone steps. Accidents necessitated frequent attendance at a casualty department. A further point was that the yard faced on to a public street with the result that the twins became the object of vulgar curiosity and the subject of crude derisory comments on the part of passers by. The distress to the mother needs no elaboration. When all the circumstances were placed before the appropriate authority the family were provided with alternative housing which satisfied the need for privacy and safety.

A further measure of relief was afforded the mother when the twins were enrolled at an occupation centre which they attended daily, transport being provided. Both children were described as ineducable when examined by a medical officer of the City of Leeds School Health Service before enrolment at the age of 3 years 10 months. Their behaviour was considered to correspond to an approximate age of 2 to $2 \frac{1}{2}$ years according to Terman-Merrill standards, Michael showing greater ability and response than Jane.

The heavy demands on the mother made by the twins during their life-time had made the parents 
determined not to have more children. With the death of both children the father sought expert advice which was secured for him.

\section{Pathology}

The findings at necropsy and the histological and histochemical features have already been described in detail (Dawson, 1954). The girl's brain was not available for examination. Among features common to both children were infiltrative changes involving the liver, spleen and the central nervous system; disturbed development of bone and cartilage; and bronchopneumonia. Both hearts were enlarged, showed changes affecting the mitral valves, had pale myocardia and macroscopically recognizable occlusion of the coronary vessels. Microscopically the coronary occlusion was seen to be due to infiltrative thickening of the intima and was associated with infiltrative changes involving the cardiac muscle fibres and related connective tissues (Fig. 16). Cardiac changes were more marked in the girl than in the boy. The nature of the infiltrate has been fully discussed elsewhere by Dawson. He arrived at the

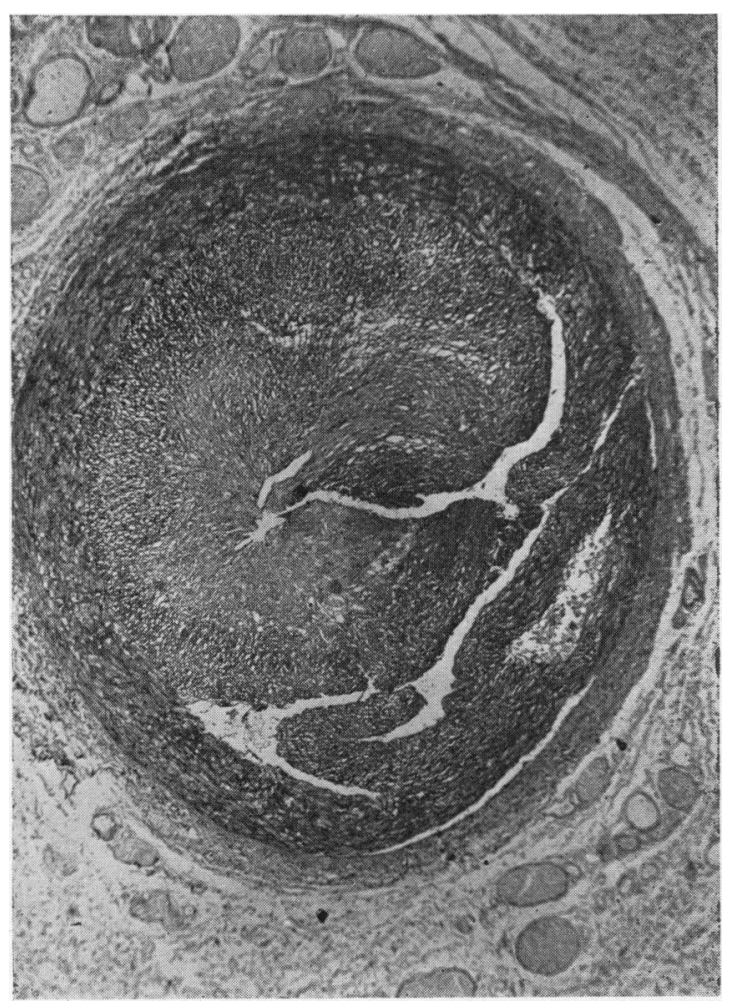

Fig. 16.-Photomicrograph $(\times 300)$ of coronary artery of Michael showing infiltrative thickening of intima. conclusion that in the brain the infiltrate possessed many of the properties of a phospholipid while in other sites it appeared to be a mucopolysaccharide.

\section{Comments}

It is generally accepted that gargoylism is a condition arising from the abnormal storage in the body of a substance as yet not completely identified. From a study of the literature it is evident that the clinical course and pathological findings in gargoylism are subject to many variations. Clinically the picture may be recognized in infancy, childhood or adult life. In its complete form there is widespread involvement of many tissues and organs throughout the body resulting in physical and mental handicap. At the other extreme there are the formes frustes which may depend for initial clinical recognition upon the presence of a gargoylelike face and mental defect (Jervis, 1950). It has been suggested that exceptionally the central nervous system may escape involvement (Strauss, Merliss and Reiser, 1947).

The twins who are the subject of this article were both examples of gargoylism in its complete form. Deformities of the bony skeleton, enlargement of the liver and spleen, opacity of the corneae and mental defect were clinically recognizable in both children. While the complete form was not attained until the age of 15 months in the boy and until the age of 19 months in the girl the first evidences were detectable very much earlier. If the father's account of his reactions on seeing his newly born infants be accepted it is reasonable to assume that abnormal facio-cranial features were present in the boy at birth. These abnormalities certainly were present by the end of the first month to judge by the independent observations of the grandmother. The fact that a few months elapsed before similar features were noticed in the twin girl was in all probability a measure of the slower development of the condition throughout the first year of life. It is to be noted that there was no evidence of actual enlargement of the crania in the radiograph taken two weeks before the onset of labour and difficulty was not experienced in the delivery of the head of either infant.

Clinical observations suggest that the underlying pathological process in the boy was in advance of that in the girl during the first 12 to 14 months of life, and thereafter it appeared to lose momentum whereas in the girl it pursued a slow, unrelenting course to the time of her death. Physical handicap reached its maximum in Michael at the age of 18 months. Thereafter his activities increased, his 
behaviour became more natural and his mental alertness improved. Extension of the corneal opacities appeared to be arrested. In contrast Jane's condition deteriorated progressively and uninterruptedly after her first birthday. With the passage of time and more particularly after the initial appearance of evidence of neurological involvement mental deterioration outpaced physical decline.

An acute respiratory infection was the immediate cause of death of both children. Acquired heart disease was a major contributory factor. The pathological findings in connexion with the coronary arteries are of especial interest and account for the anginal attacks experienced by the girl during the last two years of her life.

The hypertrophy of the gums noted in both twins is not a feature customarily associated with gargoylism and the reason for it was not ascertained.

Recorded studies have established that gargoylism is an example of recessive inheritance. Two forms of genetic determination are recognized. There is the form attributable to a sex-linked recessive gene. The number of recorded examples is small but a feature common to the children involved has been clarity of the corneae (Millman and Whittick, 1952). The other form is determined by an autosomal recessive gene. Of different sexes, the twins described in this article belong to this second form and it is to be noted that there were corneal opacities in both children. It seems probable that the dwarfs two generations earlier on the maternal side were instances of the formes frustes or alternatively of some related 'storage disease'.

\section{Summary}

Gargoylism affecting a twin brother and sister is described.

The clinical life-histories are compared and suggest that the rate of development of the underlying pathological process differed in the two children.
Clinical features of particular interest were grossly hypertrophied gums in both children, and typical anginal attacks in the girl.

The pathological findings at necropsy are outlined.

The boy died at the age of 4 years 8 months and the girl at the age of 7 years. In each case death was due to acute respiratory infection, and acquired cardiac disease (including infiltrative occlusion of the coronary arteries) was a contributory factor.

The social problems arising in the course of management are mentioned.

It is considered that gargoylism in the twin brother and sister was determined by a recessive autosomal gene and that several members in a previous generation on the maternal side were probably examples of the formes frustes without associated mental impairment.

I am indebted for invaluable help to a number of colleagues including Professor C. Polson and Dr. Ian Dawson for pathological reports; Professor Talmage Read for dental reports and illustrations; Dr. I. G. Davies, Medical Officer of Health, the City of Leeds for permission to reproduce Fig. 2; Dr. I. Holoran, Mr. J. M. P. Clark, F.R.C.S., Professor P. J. Moir, F.R.C.S., Mr. J. Foster, F.R.C.S., Dr. O. C. Carter, and Mr. W. Blackledge of the University of Leeds Photographic Department. Dr. M. F. Buchanan and Dr. C. Perera gave great assistance in collecting photographs and records. I am particularly indebted to Dr. D. Taverner for help with translations; to Mr. T. J. Shields, Librarian, the British Medical Association, for help in securing references; and to the parents for their generous understanding in agreeing to the use of photographs of their children.

\section{REFERENCES}

Dawson, I. (1954). J. Path, Bact. In the press (Cases II and IV). Hunter, C. (1917). Proc. roy. Soc. Med., 10, 104 (Section for the Study of Disease in Children).

Jervis, G. A. (1950). Arch. Neurol. Psychiat., Chicago, 63, 681. Millman, C. G. and Whittick, J. W. (1952). J. Neurol. Neurosurg. Psychiat. 15, 253.

Nonne, M. (1925). Disch. Z. Nervenheilk., 83, 263.

Straus, R., Merliss, R. and Reiser, R. (1947). Amer. J. clin. Path., 17, 671 . 